\title{
POLITICAL KNOWLEDGE AND THE LOGIC OF VOTING: A COMPARATIVE STUDY
}

\author{
Marta Fraile \\ Estudio/Working Paper 2006/223 \\ April 2006
}

Marta Fraile is Associate Professor of Political Science at the Center for Advanced Study in the Social Sciences, Juan March Institute and at the Universidad Autónoma de Madrid. 
This paper forms part of a collective research project on Empirical Democratic Theory coordinated by José María Maravall and Ignacio Sánchez-Cuenca. Previous papers of the project include:

1. José María Maravall, The Political Consequences of Internal Party Democracy, $(2003 / 190)$

2. Ignacio Sánchez-Cuenca, How Can Governments Be Accountable If Voters Vote Ideologically, (2003/191)

3. Belén Barreiro, Explaining the Electoral Performance of Incumbents in Democracies, (2004/200)

4. Paloma Aguilar and Ignacio Sánchez-Cuenca, ¿Gestión o representación? Los determinantes del voto en contextos políticos complejos, (2005/220)

5. Sonia Alonso, Enduring Ethnicity: The Political Survival of Incumbent Ethnic Parties in Western Democracies, (2005/221)

6. Carles Boix, Constitutions and Democratic Breakdowns, (2005/222) 


\section{Introduction}

This paper will examine the decision making process by which individual voters cast their ballots. In particular, it will discuss two traditional explanations of electoral behaviour: ideological voting and performance voting. These explanations of voting share a common assumption: electors' decisions are based on what they expect to get from their choice. Each potential outcome has a benefit or a cost, and citizens might choose the one benefiting them most or costing them least. That is, voters will maximize the utility of their electoral decision. In order to maximize the utility of a given decision an individual needs to have a certain amount of information at hand.

Previous research has explained the simple and straightforward decision rule at work in both ideological and performance voting. In the case of ideological voting, citizens vote for the party that is perceived closer to their ideal position on the left-right dimension. Given the lack of perfect information for the electorate, Downs conceived ideology as an information saving device. That is, a perceptual cue that helps ordinary citizens to have a general idea about the policy positions of the main parties of their political system. In the case of performance voting, citizens decide on a standard of what they consider good performance, and reward the incumbent if this standard has been achieved, punishing the incumbent otherwise. Again, governments' performance is often considered as a particular low-cost indicator that any given citizen can use as a heuristic tool to decide her vote in place of more costly and less salient information (such as electoral manifestos, or policies).

Yet in order to be able to judge incumbent governments by their performance or by their ideologies, voters must have a certain degree of information and factual knowledge such as the state of the economy, international politics, or the ideological positions of each of the policies included in parties' manifestos. However, research on public opinion and voting behaviour from Converse $(1964,1970)$ onwards often indicates that the overall level of information, knowledge and comprehension of politics amongst the average citizen is relatively poor. We need therefore to systematically consider the degree of information and factual 
political knowledge citizens have at their disposal. Does political knowledge mediate the logic of ideological or performance voting $?^{1}$

While models of ideological or performance voting generally assume that all citizens are similarly informed and equally guided by the same considerations or motives (Downs, 1957; Kramer, 1971 and 1983; Kinder and Kiewiet, 1979 and 1981), in this paper I analyze the extent to which the electors' degree of factual political knowledge influences their decision-rules when casting their ballot. Previous literature has provided contradictory answers to this question. For instance, Krause (1997) finds that uninformed citizens are less likely to vote on the basis of government's performance, but Zaller (1992, and 2004) argues the opposite. According to Zaller, poorly informed citizens are more likely to vote on the basis of performance or other currently salient issues, whereas informed electors use an ideological logic when deciding their vote. This is very much the opposite of Fearon's views about retrospective voting on the grounds of performance. As he puts it,

\footnotetext{
"There can be no doubt that formidable problems are involved in monitoring and evaluating incumbent behavior to make informed judgements about whether to reelect (...) Voters have neither the time to follow policy debates... nor the training and skill to evaluate conflict "expert" arguments about what is best" Fearon, 1999: 68).
}

Performance voting thus requires a considerable amount of political knowledge. Rational voters would only use the logic of performance if they are well-informed: therefore, the conclusion would be that political knowledge is positively related to performance voting, and negatively related to ideological voting.

We have therefore contradictory arguments about the relationship between political knowledge, on the one hand, and performance and ideological voting on the other. To answer these questions, I provide empirical evidence from post-electoral survey data for parliamentary elections held in four different polities: Spain, Hungary, Poland, and Portugal. The data come from the CSES Module 2 third advance release dataset - June, 2005, where

${ }^{1}$ In this paper I use the concept of political knowledge referring to factual political knowledge of citizens (Delli Carpini and Keeter, 1996). This implies knowledge about rules, actors, the relevant political issues of the polities, and the capacity of individual citizens to influence the political outcome. Other scholars use other terms to refer to the same topic as, for instance, political awareness (Zaller, 1992) or political sophistication (Luskin, 1990). 
comparable information about citizens' degree of political knowledge is available across countries. By selecting countries with diverse political structures, I will be able to test whether the effect of political knowledge on the logic of voting is common across individuals in diverse polities.

I proceed in four parts. First, in section 2 I review the literature on the logic of ideological and performance voting and discuss the critical assumption that both theories share: that this logic of voting can be used to the same extent by all citizens, independently of their degree of political expertise. I present specific hypotheses regarding the likelihood of citizens to rely on this logic depending on their level of political knowledge. I follow this with a section discussing issues of data and case selection in section 3. After testing my hypotheses in section 4 , I conclude that while the influence of political knowledge is clear on performance voting across polities, the effect is less conclusive on ideological voting. I finally discuss the broader implications of these empirical results for the theories on ideological and performance voting.

\section{The argument: Why political knowledge?}

The ideological logic of voting was initially proposed by Downs (1957). His departure point was that voting decisions can be explained as rational behaviour. When faced with a decision that affects her interests, the individual will choose the most cost-effective means of maximizing her gains. An action that maximizes utility is rational. For a citizen to take such rational action, however, she needs to rank her preferences in transitive order and choose her most preferred alternative. This citizen, then, will always make the same decision if presented with the same set of alternatives in different points in time (Downs, 1957: 6). These criteria assume that citizens have information at hand that allows them to make their choices.

But individuals do not always have a clear notion of what they want as an outcome of their actions, of how the alternatives relate to such outcome, or of how the different outcomes relate to their own interests. Therefore Downs assumed that citizens do not take their political 
decisions under conditions of perfect information. Rather, they live in a world of uncertainty where they search for information before coming to a decision. Information gathering, and processing it, is however, a costly action. Hence, some voters might be able and motivated to invest time and resources to collect information whereas others might not. Under these conditions, parties' ideologies appear to be information short-cuts for voters who cannot judge politics expertly. The ideological labels of parties then guide non-expert citizens about the general political intentions of parties. More specifically, ideologies can order on a single policy dimension the programmes of political parties. The main assumption of Downs is that the majority of policy issues are related and can be included in this single political dimension. In sum, ideology appears as an information saving device or heuristic (Popkin, 1991; Sniderman et. al., 1991) that citizens use to guide their political decisions.

Nevertheless some electors might encounter difficulties both in defining their own preferences in the ideological dimension and in placing the political parties' policies. In fact, survey research on citizens' attitudes has shown that the public in general presents low levels of factual political knowledge. Moreover the competences needed to form and express consistent opinions appear to be limited (Althaus, 2003, Converse, 1970; Bennet, 1988 and 1989; Delli Carpini and Keeter, 1996). If citizens are politically ignorant, they may not be able to organize consistently their opinions by their ideology. In this case the ideological labels of parties would not work as a shortcut for ignorant citizens to decide their vote. Previous research has shown that there are significant differences in the structure and stability of political attitudes and ideology among knowledgeable and ignorant citizens (Bartle, 1997; Delli Carpini and Keeter, 1996; Sinnott, 2000): the former have more consistent political ideologies, opinions and attitudes. Therefore, in order to use ideology as a criterium for voting, electors need some amount of information. Voters with little information about the positions of candidates on important issues will use ideology to cast their votes to a lesser extent than knowledgeable citizens.

There is, however, another possible argument about the role of factual political knowledge on ideological voting. For ideology to work as an information saving device, citizens should know something about politics but not to the extent that they become experts. If this were the case, the effect of political knowledge on ideological voting would be non 
linear. Moderately knowledgeable citizens might rely on the ideological logic of voting to a greater extent than either ill informed citizens or perfectly well informed citizens. Studying the influence of political knowledge on information diffusion and opinion change, Zaller (1992) finds a non-monotonic relationships between political knowledge and opinion change in response to messages from the mass media. Well-informed citizens are more likely than poorly informed ones to receive and to understand such messages but, at the same time, they are less likely to change their own opinions. Moderately well-informed citizens show the greatest levels of media-induced opinion change in comparison with both ill-informed and well-informed citizens.

Therefore, empirical evidence shows that some people tend to be more informed than others. This variance is unevenly distributed, since the highest degree of political knowledge is concentrated among the politically and socially advantaged. Much of the empirical variation in the propensity to know about politics is explained by individual differences in motivation, ability, and opportunity (Althaus, 2003; Bennet, 1995; Delli Carpini and Keeter, 1996). ${ }^{2}$ The main question that I shall examine is the extent to which variations in factual political knowledge influence voters' propensity to use ideology when casting their ballots. More informed voters will have a consistent, ideologically sophisticated interpretation of the world. I expect to find that the likelihood of using ideology as a criterium to decide which party to vote will be higher among voters with medium or high levels of political expertise than among those with a low level of political knowledge.

The logic of performance voting is apparently very simple. When deciding how to vote electors seek to maximize their utility from the outcomes of the policies implemented by the incumbent. Hence, in the logic of performance voting citizens are guided by outcomes rather than policies. They calculate a threshold of general welfare and, if they consider that the incumbent has achieved this, they re-elect the government. For the logic of performance

\footnotetext{
${ }^{2}$ The discussion about the sources of differences in the levels of citizens' factual political knowledge is beyond the scope of this paper, but according to Althaus (2003), motivation to became informed seems to depends on interest in politics, and sense of civic duty; the ability to process political information is enhanced by education and by routine exposure to daily news whereas opportunities to become informed depends on the content of available news coverage, geographical location of the citizen, and some other contextual characteristics of the place where the individual lives. (see also Bennet, 1995; Delli Carpini and Keeter, 1996)
} 
voting to work, however, electors need political information. They need to know which party is (or are, in the case of coalition governments) in government; what changes have taken place during the mandate in economic conditions, international politics, or whatever outcomes they consider relevant; and the extent to which the incumbent government is responsible for such outcomes.

When voters are poorly informed about politics, these three conditions might not be present. If this is the case, citizens will not decide their vote on the basis of an informed evaluation of government's performance. Factual political knowledge helps people to better assess their interests as individuals and as members of groups. It is a key determinant of instrumental rationality (Delli Carpini and Keeter, 1996). The more knowledgeable citizens are, the better will they understand the impact of public policies on their own interests, and the more likely will they vote on the basis of performance. Studies about voting as a response to the economic performance of government have often treated the electorate as undifferentiated, ignoring systematic heterogeneity among voters (exceptions are Althaus, 2003; Gómez and Wilson, 2001 and 2006; Krause, 1997). My claim here is that we need to test the extent to which performance voting is influenced by the degree of factual political knowledge of citizens. The theoretical expectations to be tested in this paper are summarised in Table 1. 
The influence of factual political knowledge

\section{IDEOLOGICAL VOTING}

Authors

Hypotheses

No effect of citizens' factual political knowledge on the

Downs, 1957 and later interpretations: propensity to vote according to ideology $\Rightarrow$ ideology for example, Popkin, 1991. operates as an information saving device or heuristic that citizens use to guide their political decisions. Therefore, the propensity to vote ideologically will be homogeneous across citizens independently of their political expertise

The propensity to vote ideologically will be heterogeneous

A refutation of the assumptions of Downs and others. across citizens, depending on their political expertise $\Rightarrow$ The likelihood of using ideology will be higher among voters with medium or high levels of political knowledge

\section{THE LOGIC OF PERFORMANCE VOTING}

Authors

Hypotheses

No influence of citizens' factual political knowledge on

Key, 1966 and later interpretations: their propensity to vote according to performance $\Rightarrow$ Kramer, 1971 and 1983; Kiewiet, performance constitutes a heuristic that citizens use to 1983; Kinder and Kiewiet, 1979 and guide their political decisions. Therefore, the propensity to 1981, etc. vote looking at the performance of the government will be homogeneous across citizens independently of their political expertise

The propensity to vote according to the performance of A refutation of the assumption of Key, 1966: the heterogeneous economic voting behaviour (Althaus, 2003; Gómez and Wilson, 2001, 2006; Krause, 1997). the government will be heterogeneous across citizens, depending on their political expertise $\Rightarrow$ As citizens become more knowledgeable about politics, their propensity to vote on the basis of performance will increase

(Source: my own elaboration. In italics the hypotheses to be tested in this paper) 
To sum up, both ideological and performance voting explain individual voting as the product of a rational decision. For a decision to be rational, a certain amount of information is needed. I expect the likelihood of ideological and performance voting to increase as the level of factual political knowledge grows. Studies which explore the influence of political knowledge on voting decisions are scarce (but see Andersen et al., 2001; Bartels, 1996; Gómez and Wilson, 2001; Krause, 1997; Zaller, 2002 and 2004). I shall now analyse postelectoral survey data from four different polities.

\section{Data and cases}

I want to test the comparative effect of political expertise on ideological and performance voting in the European multiparty systems. Here voters will find more difficulties in selecting which party is ideologically closer to their position than in two party systems. In addition, multiparty systems are often related to coalition governments where performance voting requires greater political knowledge for voters to hold the government responsible for outcomes. Thus, both ideological and performance voting will require comparatively more information for rational voters who want to cast their vote according to ideological proximity or retrospective assessments of performance.

The CSES project provides comparable post-electoral survey data for different countries. In each country, national probability samples of the adult population were interviewed shortly after a national election. A problem with post-electoral surveys is that the levels of political knowledge might be overestimated: in electoral campaigns voters get the highest degree of political information of the whole legislature. Acquiring information at those times is less costly than in the middle of a mandate. Political knowledge can also be higher when elections are very competitive and political tension is high. ${ }^{3}$

${ }^{3}$ The levels of political knowledge estimated in post-electoral surveys are especially high for Poland in comparison with the rest of countries included in the analysis. (see descriptive statistics in the Appendix: Tables A. 1 and A.2) 
Nevertheless, this bias in the level of political knowledge goes in the same direction across countries. Moreover the overestimation of citizens' political knowledge goes against my main hypothesis -that both ideological and performance voting are influenced by variations in voters' political knowledge. Political knowledge some weeks after an election should be more uniformly distributed than in the middle of a mandate.

I have chosen four different polities from the CSES Module 2 (June, 2005). I use this comparative design in order to examine the robustness of the hypotheses proposed in Table 1. That is, whether ideological or performance voting is mediated by citizens' political knowledge across different polities. The countries present considerable variations -on their democratic history, the complexity of their multiparty systems, the level of competition of the campaigns, the extent of electoral participation, the type of government, and the performance of the economy. Table 2 summarizes all these features. It classifies each election according to the degree of competitiveness and the level of turnout. It also provides information on the political systems: which was the incumbent party at the time of election, whether the government was a coalition or not, whether the government had majoritarian support in parliament or not. All of the elections resulted in a government change. Economic performance was particularly bad in Portugal and Poland -where the government was also accused of corruption. In contrast, the economic performance in Hungary and Spain was relatively good, though policies implemented by the governments were unpopular (such as the Spanish military participation in the Irak war $^{4}$ ) and the Hungarian government was accused of corruption.

Table 2 also classifies the electoral campaigns carried out in each country as based on ideology or performance. ${ }^{5}$ The campaign was clearly dominated by performance in Hungary, Poland, and Portugal. In the case of Hungary this was mixed up with the nationalist agenda of the conservative Fidesz-MPP government. In Poland the dominant topic was the rise of

\footnotetext{
${ }^{4}$ There were a number of other controversial or unpopular policies implemented by the conservatives in Spain, such as the territorial organization of the Spanish state, or the Ebro water transfer. The conservative government also had to face a national-level general strike. (Torcal and Rico, 2004)

${ }^{5}$ This classification is based on reports about each election in Electoral Studies (2002-2004) as well as on documentation from the CSES project.
} 
unemployment, the public budget deficit, and the increasing differences in living conditions between rural and urban areas. (CSES, 2005). In Portugal, the deep economic crisis as well as the public deficit were the main issues of the electoral campaign (Costa et al., 2004). The Spanish campaign was a mixed one: the conservative government emphasized economic performance and "Spanish nationalism" against Basque demands. The opposition focused the campaign on unpopular policies such as the participation in the Irak war, and social and educational reforms.

Table 2. The political context of elections in the four countries

\begin{tabular}{|c|c|c|c|c|}
\hline & Spain & Portugal & Poland & Hungary \\
\hline Incumbent party & $\begin{array}{l}\mathrm{PP} \\
\text { (conservative) }\end{array}$ & $\begin{array}{l}\text { PS } \\
\text { (socialdemocratic) }\end{array}$ & $\begin{array}{l}\text { AWSP } \\
\text { (conservative) }\end{array}$ & $\begin{array}{l}\text { Fidesz-MPP } \\
\text { (conservative) }\end{array}$ \\
\hline $\begin{array}{l}\text { Support and composition } \\
\text { of the incumbent }\end{array}$ & Majority & Majority & Coalition & Coalition \\
\hline Change of government & $\begin{array}{l}\text { Yes (PSOE } \\
\text { socialdemocratic) }\end{array}$ & $\begin{array}{l}\text { Yes (PSD, } \\
\text { center-right) }\end{array}$ & $\begin{array}{l}\text { Yes (socialdemocratic } \\
\text { coalition: SLD+UP) }\end{array}$ & $\begin{array}{l}\text { Yes (socialdemocratic } \\
\text { coalition: MSZP+ } \\
\text { SZDSZ) }\end{array}$ \\
\hline $\begin{array}{l}\text { Performance previous } \\
\text { to elections }\end{array}$ & Regular & $\mathrm{Bad}$ & $\mathrm{Bad}$ & Regular \\
\hline $\begin{array}{l}\text { Degree of } \\
\text { competitiveness }\end{array}$ & High & High & Low & High \\
\hline Main opposition parties & PP-PSOE & PS-PSD & Dispersed & MSZP and Fidesz \\
\hline $\begin{array}{l}\text { Dominant topic in the } \\
\text { electoral campaign }\end{array}$ & $\begin{array}{l}\text { Mixed } \\
\text { campaign }\end{array}$ & $\begin{array}{l}\text { Performance } \\
\text { campaign }\end{array}$ & $\begin{array}{l}\text { Performance } \\
\text { campaign }\end{array}$ & $\begin{array}{l}\text { Performance } \\
\text { campaign }\end{array}$ \\
\hline Turnout & $70 \%$ & $62.3 \%$ & $43.6 \%$ & $70.5 \%$ \\
\hline Date of election & March, 2004 & March, 2002 & September, 2001 & April, 2002 \\
\hline
\end{tabular}

(Source: my own elaboration based on www.parties-and-elections.de and on reports of Electoral Studies)

\section{Empirical results}

I test the hypothesis about the influence of political knowledge on ideological and performance voting with a multinomial logit equation. Declared vote is the dependent 
variable. In order to contrast the vote for the incumbent and the main opposition party across countries, the results from the multinomial logit estimations correspond only to this dichotomy. Each equation indicates the propensity to vote for the incumbent party versus its main challenger.

The two variables concerning performance and ideological voting are specified as follows. First, retrospective judgements of performance are a dichotomous variable taking the value 0 (for bad and very bad opinion) and 1 (for good and very good). ${ }^{6}$ Second, ideological voting is tested through two variables measuring the quadratic distance of each voter's ideological position with respect to the ideological position attributed by her to both the incumbent party and the main opposition party. ${ }^{7}$

Other independent variables in the voting equations across countries have been specified as follows. Age varies from 18 to 99 years old. Gender is a dummy variable, taking the value 1 for female and 0 for male. Education takes the values 1 (low education), 2 (medium education) and 3 (maximum education) in the case of Hungary, and ordinal values in Poland, Portugal and Spain (ranging from no education at all to university education). ${ }^{8}$ The last variable indicates the labour market position of respondents. ${ }^{9}$ Descriptive statistics of all the variables are given in the Appendix (Tables A.1). ${ }^{10}$

\footnotetext{
${ }^{6}$ The question was the following: "Now thinking about the performance of the government in general, how good or bad a job do you think the government did over the past [number of years between the previous and the present election or change in government] years. Has it done a very good job? A good job? A bad job? A very bad job?"

${ }^{7}$ More specifically, the ideological distance is specified as follow: $\left(x_{i}^{*}-x_{i}^{G}\right)^{2}$

Where $x_{i}^{*}$ is voter $i$ ideological position in a scale that goes from 0 (extreme left) to 10 (extreme right) and $x_{i}^{G}$ is the ideology attributed to the incumbent party (and its main challenger) by the same voter $i$.

${ }^{8}$ For Hungary education has been specified in the equations as a categorical variable taking the intermediate value as the reference category whereas for Poland, Portugal and Spain the variable has been specified in the voting equations as ordinal variables.

${ }^{9}$ The categories of this variable are the following: 1 employed, 2 home duties, 3 unemployed, 4 students, and 5 retired. I have specified this variable in the equations as categorical, taking the retired as the category of reference.

${ }^{10}$ I also used the class scheme of Erikson and Goldthorpe (1993), collapsing it in six different classes: 1 (service class), 2 (middle class), 3 (urban bourgeoisie), 4 (rural bourgeoisie), 5 (skilled and semi-skilled
} 
Political knowledge is based on three different answers to the CSES questionnaire. Table 3 reproduces the questions used in each of the countries, showing the percentages of correct answers. Although the questions are different across countries, they were specifically designed to allow for cross national comparison.

Table 3. Survey questions of political knowledge. Percentage of correct responses to each of the questions

\begin{tabular}{|c|c|c|c|c|}
\hline $\begin{array}{l}\text { Degree of } \\
\text { difficulty of } \\
\text { the question }\end{array}$ & Spain (2004) & Portugal (2002) & Poland (2001) & Hungary (2002) \\
\hline $\begin{array}{l}\text { Item } 1 \\
\text { (easy) }\end{array}$ & $\begin{array}{l}\text { Do you happen to } \\
\text { remember the name } \\
\text { of the first president } \\
\text { of government in our } \\
\text { democracy? } \\
70 \%\end{array}$ & $\begin{array}{l}\text { Do you happen to } \\
\text { remember the name } \\
\text { of the Portuguese } \\
\text { Prime Minister before } \\
\text { António Guterres? } \\
92 \%\end{array}$ & $\begin{array}{l}\text { Who is the } \\
\text { chairman of the } \\
\text { SLD? } \\
77 \%\end{array}$ & $\begin{array}{l}\text { Do you know who } \\
\text { presides over the } \\
\text { Constitutional Court? } \\
67 \%\end{array}$ \\
\hline $\begin{array}{l}\text { Item } 2 \\
\text { (medium) }\end{array}$ & $\begin{array}{l}\text { In what year was the } \\
\text { Spanish Constitution } \\
\text { approved? } \\
40 \%\end{array}$ & $\begin{array}{l}\text { Do you happen to } \\
\text { remember the number } \\
\text { of EU member- } \\
\text { states? } \\
40 \%\end{array}$ & $\begin{array}{l}\text { Who currently is } \\
\text { the President of } \\
\text { Russia? } \\
75 \%\end{array}$ & $\begin{array}{l}\text { Do you know what } \\
\text { percentage of the } \\
\text { votes a party must get } \\
\text { in order to have some } \\
\text { of its candidates sent } \\
\text { to the new } \\
\text { parliament? } \\
65 \%\end{array}$ \\
\hline $\begin{array}{l}\text { Item } 3 \\
\text { (difficult) }\end{array}$ & $\begin{array}{l}\text { Do you know how } \\
\text { many countries are } \\
\text { members of the } \\
\text { European Union at } \\
\text { the present time? } \\
31 \%\end{array}$ & $\begin{array}{l}\text { Number of district } \\
\text { level candidates } \\
\text { correctly identified } \\
\text { by respondents (at } \\
\text { least one or more) } \\
19 \%\end{array}$ & $\begin{array}{l}\text { Could you please } \\
\text { name the military } \\
\text { alliance of which } \\
\text { Poland is currently } \\
\text { a member? } \\
75 \%\end{array}$ & $\begin{array}{l}\text { Number of politicians } \\
\text { correctly identified } \\
\text { (at least one or more) } \\
13 \%\end{array}$ \\
\hline
\end{tabular}

To create the variable, first the number of correct responses were added (taking the values from 0 -all responses incorrect to 3 - all responses correct). I consider no responses as

workers), and 6 (non skilled workers). However none of these categories turned out to be statistically significant in the voting equations, and consequently this class variable was excluded from the equation. The results with the effect of the six categories' class variable are available to the interested reader. Recall that the occupational codes included in the CSES module employ only the first two digits of 1988 ISCO / ILO International Standard Classification of Occupations. This does not provide satisfactory information to properly classify the individuals' class position. Hence, I do not discard the possibility that this variable did not turn out to be significant across the equations given this lack of detailed information. 
incorrect answers. Then, the resulting score was recoded from 0 to 1 . $^{11}$ Additional information on political knowledge would have improved the analysis, but this proxy was the best that could be done with the data available -moreover, a similar variable has already been used in comparative political analyses (see, for instance, Millner, 2002, and Toka, 2003).

Tables 4 through 7 present the results of the logic of voting for each country. The columns of equation 1 in each of the four tables confirm the existence of both ideological and performance voting across countries. Moreover, the coefficients that show the effect of ideological distance from both the incumbent and the opposition parties are all statistically significant. The sign is also correct across countries: coefficients are negative for ideological distance from the incumbent, and positive for ideological distance from the main opposition party (what the tables show is the effect of each independent variable on the propensity to vote for the incumbent versus the main opposition party). The coefficients that indicate the effect of retrospective evaluations of performance are also statistically significant and with positive signs in all the countries. Positive assessments about governmental performance increase the likelihood to vote for the incumbent. In sum, there is clear evidence of both ideological and performance voting across countries.

I shall turn now to analyse the influence of political knowledge on the propensity to vote according to performance and to ideology. In order to assess such influence I specify an interaction term between political knowledge and each of the three variables for ideological and performance voting. That is, an interaction term between political knowledge and ideological distance from the incumbent (equation 2 in each of the tables); another interaction term between political knowledge and ideological distance from the main opposition party in equation 3; and finally an interaction term between political knowledge and assessments of government performance in equation 4 .

\footnotetext{
${ }^{11}$ Through the following metric transformation of the variable: $K=\frac{X-X_{\min }}{X_{\max }-X_{\min }}$
} 
Table 4. Voting for the incumbent in Hungary (only coefficients of the comparison among the incumbent and the main opposition party are given)

\begin{tabular}{|c|c|c|c|c|c|c|c|c|}
\hline \multirow[b]{2}{*}{ Independent Variables } & \multicolumn{2}{|l|}{ Equation 1} & \multicolumn{2}{|l|}{ Equation 2} & \multicolumn{2}{|l|}{ Equation 3} & \multicolumn{2}{|l|}{ Equation 4} \\
\hline & Coef & SE & Coef & & Coef & & Coef & SE \\
\hline $\begin{array}{l}\text { Ideological distance } \\
\text { from the incumbent }\end{array}$ & $-0.06^{* *}$ & 0.01 & $-0.07 * *$ & 0.03 & $-0.06 * *$ & 0.01 & $-0.06^{* *}$ & 0.01 \\
\hline $\begin{array}{l}\text { Ideological distance } \\
\text { from the challenger }\end{array}$ & $0.04 * *$ & 0.01 & $0.04 * *$ & 0.01 & $0.02+$ & 0.01 & $0.04 * *$ & 0.01 \\
\hline Performance $(1=$ good $)$ & $3.17 * *$ & 0.31 & $3.19 * *$ & 0.31 & $3.15 * *$ & 0.31 & $2.34 * *$ & 0.54 \\
\hline $\begin{array}{l}\text { Index of Political } \\
\text { Knowledge }\end{array}$ & $1.30 * *$ & 0.49 & $1.17 *$ & 0.61 & 0.59 & 0.64 & -0.02 & 1.05 \\
\hline $\begin{array}{l}\text { Ideological distance } \\
\text { from the incumbent } x \\
\text { PolKnowledge }\end{array}$ & & & 0.02 & 0.03 & & & & \\
\hline $\begin{array}{l}\text { Ideological distance } \\
\text { from the challenger } \mathrm{x} \\
\text { PolKnowledge }\end{array}$ & & & & & $0.07 * *$ & 0.02 & & \\
\hline $\begin{array}{l}\text { Performance } \mathrm{x} \\
\text { PolKnowledge }\end{array}$ & & & & & & & $2.17^{*}$ & 1.11 \\
\hline Age & 0.01 & 0.01 & 0.01 & 0.01 & 0.01 & 0.01 & 0.01 & 0.01 \\
\hline Gender & 0.11 & 0.26 & 0.11 & 0.26 & 0.13 & 0.26 & 0.08 & 0.26 \\
\hline $\begin{array}{l}\text { Education (reference } \\
\text { category: } 2 \text {. Intermediate } \\
\text { level) }\end{array}$ & & & & & & & & \\
\hline 1. Minimum level & $1.06 * *$ & 0.33 & $1.07 * *$ & 0.33 & $1.11 * *$ & 0.33 & $1.02 * *$ & 0.33 \\
\hline 3. Maximum level & 0.34 & 0.38 & 0.35 & 0.38 & 0.41 & 0.38 & 0.35 & 0.39 \\
\hline $\begin{array}{l}\text { Labour Market position } \\
\text { (reference category: } \\
\text { 5. Retired) }\end{array}$ & & & & & & & & \\
\hline 1. Employed & 0.54 & 0.45 & 0.53 & 0.45 & 0.48 & 0.45 & 0.49 & 0.45 \\
\hline 2. Home-duties & $3.28 * *$ & 0.89 & $3.29 * *$ & 0.88 & $3.24 * *$ & 0.89 & $3.26 * *$ & 0.89 \\
\hline 3. Unemployed & 0.31 & 0.62 & 0.32 & 0.62 & 0.21 & 0.62 & 0.26 & 0.62 \\
\hline 4. Students & 0.15 & 0.87 & 0.15 & 0.87 & 0.05 & 0.87 & 0.07 & 0.87 \\
\hline Constant & $-3.94 * *$ & 0.90 & $-3.88 * *$ & 0.90 & $-3.55 * *$ & 0.92 & $-3.28 * *$ & 0.98 \\
\hline $\begin{array}{l}\text { Number of cases } \\
\text { LR } \chi^{2} \\
\text { Pseudo } \mathrm{R}^{2}\end{array}$ & $\begin{array}{l}872 \\
756.26 * * \\
0.438\end{array}$ & & $\begin{array}{l}872 \\
757.07 * * \\
0.438\end{array}$ & & $\begin{array}{l}872 \\
763.94 * * \\
0.442\end{array}$ & & $\begin{array}{l}872 \\
766.51 * * \\
0.446\end{array}$ & \\
\hline
\end{tabular}

(entries are logit maximum-likelihood estimates and their associated standard errors)

** Significant at the level of $99 \%$.

* Significant at the level of $95 \%$.

+ Significant at the level of $90 \%$. 
Table 5. Voting for the incumbent in Poland (only coefficients of the comparison among the incumbent and the main opposition party are given)

\begin{tabular}{|c|c|c|c|c|c|c|c|c|}
\hline \multirow{2}{*}{ Independent Variables } & \multicolumn{2}{|l|}{ Equation 1} & \multicolumn{2}{|l|}{ Equation 2} & \multicolumn{2}{|l|}{ Equation 3} & \multicolumn{2}{|l|}{ Equation 4} \\
\hline & Coef & SE & Coef & SE & Coef & & Coef & \\
\hline $\begin{array}{l}\text { Ideological distance } \\
\text { from the incumbent }\end{array}$ & $-0.04 * *$ & 0.01 & $-0.08 *$ & 0.04 & -0.04 & 0.01 & $-0.04 * *$ & 0.01 \\
\hline $\begin{array}{l}\text { Ideological distance } \\
\text { from the challenger }\end{array}$ & $0.06^{* *}$ & 0.01 & $0.06^{* *}$ & 0.01 & 0.04 & 0.03 & $0.06^{* *}$ & 0.01 \\
\hline Performance $(1=$ good $)$ & $0.84 *$ & 0.39 & $0.88 *$ & 0.40 & $0.85^{*}$ & 0.39 & -3.22 & 1.99 \\
\hline $\begin{array}{l}\text { Index of Political } \\
\text { Knowledge }\end{array}$ & 0.16 & 0.30 & 0.22 & 0.91 & 0.65 & 0.92 & 0.24 & 0.66 \\
\hline $\begin{array}{l}\text { Ideological distance } \\
\text { from the incumbent } x \\
\text { PolKnowledge }\end{array}$ & & & 0.04 & 0.04 & & & & \\
\hline $\begin{array}{l}\text { Ideological distance } \\
\text { from the challenger } x \\
\text { PolKnowledge }\end{array}$ & & & & & 0.02 & 0.03 & & \\
\hline $\begin{array}{l}\text { Performance } x \\
\text { PolKnowledge }\end{array}$ & & & & & & & $4.58 * *$ & 1.09 \\
\hline Age & 0.00 & 0.01 & 0.00 & 0.01 & 0.00 & 0.01 & 0.00 & 0.01 \\
\hline Gender & -0.14 & 0.24 & -0.15 & 0.24 & -0.15 & 0.24 & -0.16 & 0.24 \\
\hline Education & $0.21 *$ & 0.09 & $0.20 *$ & 0.09 & $0.20 *$ & 0.09 & $0.20 *$ & 0.09 \\
\hline $\begin{array}{l}\text { Labour Market position } \\
\text { (reference category: } \\
\text { 5. Retired) }\end{array}$ & & & & & & & & \\
\hline 1. Employed & -0.10 & 0.39 & -0.13 & 0.39 & -0.12 & 0.39 & -0.14 & 0.39 \\
\hline 2. Home-duties & 0.52 & 0.54 & 0.50 & 0.54 & 0.50 & 0.54 & 0.50 & 0.54 \\
\hline 3. Unemployed & -0.47 & 0.59 & -0.44 & 0.58 & -0.46 & 0.59 & -0.48 & 0.59 \\
\hline 4. Students & 0.18 & 0.74 & 0.15 & 0.74 & 0.17 & 0.74 & 0.15 & 0.75 \\
\hline Constant & $-1.67 *$ & 0.97 & -1.64 & 1.22 & $-2.10+$ & 1.21 & -1.64 & 1.09 \\
\hline $\begin{array}{l}\text { Number of cases } \\
\text { LR } \chi^{2} \\
\text { Pseudo } \mathrm{R}^{2}\end{array}$ & $\begin{array}{l}733 \\
472.49 * * \\
0.254\end{array}$ & & $\begin{array}{l}733 \\
476.15 * * \\
0.258\end{array}$ & & $\begin{array}{l}733 \\
474.69 * * \\
0.257\end{array}$ & & $\begin{array}{l}733 \\
481.88 * * \\
0.271\end{array}$ & \\
\hline
\end{tabular}

(entries are logit maximum-likelihood estimates and their associated standard errors)

** Significant at the level of $99 \%$.

* Significant at the level of $95 \%$.

+ Significant at the level of $90 \%$. 
Table 6. Voting for the incumbent in Portugal (only coefficients of the comparison among the incumbent and the main opposition party are given)

\begin{tabular}{|c|c|c|c|c|c|c|c|c|}
\hline \multirow{2}{*}{ Independent Variables } & \multicolumn{2}{|l|}{ Equation 1} & \multicolumn{2}{|l|}{ Equation 2} & \multicolumn{2}{|c|}{ Equation 3} & \multicolumn{2}{|l|}{ Equation 4} \\
\hline & Coef & SE & Coef & & Coef & SE & Coef & \\
\hline $\begin{array}{l}\text { Ideological distance } \\
\text { from the incumbent }\end{array}$ & $-0.13 * *$ & 0.02 & $-0.15^{* *}$ & 0.03 & $-0.13 * *$ & 0.02 & $-0.13 * *$ & 0.02 \\
\hline $\begin{array}{l}\text { Ideological distance } \\
\text { from the challenger }\end{array}$ & $0.11 * *$ & 0.01 & $0.11 * *$ & 0.01 & $0.09 * *$ & 0.03 & $0.11 * *$ & 0.01 \\
\hline Performance $(1=$ good $)$ & $1.77 * *$ & 0.26 & $1.77 * *$ & 0.26 & $1.76 * *$ & 0.26 & 0.70 & 0.53 \\
\hline $\begin{array}{l}\text { Index of Political } \\
\text { Knowledge }\end{array}$ & -0.15 & 0.44 & -0.31 & 0.50 & -0.27 & 0.53 & -0.69 & 0.49 \\
\hline $\begin{array}{l}\text { Ideological distance } \\
\text { from the incumbent } x \\
\text { PolKnowledge }\end{array}$ & & & 0.03 & 0.06 & & & & \\
\hline $\begin{array}{l}\text { Ideological distance } \\
\text { from the challenger } x \\
\text { PolKnowledge }\end{array}$ & & & & & 0.04 & 0.05 & & \\
\hline $\begin{array}{l}\text { Performance } x \\
\text { PolKnowledge }\end{array}$ & & & & & & & $2.82 * *$ & 1.01 \\
\hline Age & -0.01 & 0.01 & -0.01 & 0.01 & -0.01 & 0.01 & -0.01 & 0.01 \\
\hline Gender & -0.37 & 0.24 & -0.38 & 0.24 & -0.37 & 0.24 & -0.36 & 0.24 \\
\hline Education & -0.08 & 0.08 & -0.08 & 0.08 & -0.08 & 0.08 & -0.06 & 0.08 \\
\hline $\begin{array}{l}\text { Labour Market position } \\
\text { (reference category: } \\
\text { 5. Retired) }\end{array}$ & & & & & & & & \\
\hline 1. Employed & -0.20 & 0.37 & -0.20 & 0.38 & -0.23 & 0.38 & -0.18 & 0.38 \\
\hline 2. Home-duties & -0.63 & 0.45 & -0.63 & 0.45 & -0.64 & 0.45 & -0.62 & 0.45 \\
\hline 3. Unemployed & -0.08 & 0.69 & -0.08 & 0.69 & -0.09 & 0.68 & -0.04 & 0.69 \\
\hline 4. Students & -0.79 & 0.86 & -0.81 & 0.85 & -0.80 & 0.86 & -0.67 & 0.86 \\
\hline Constant & 0.85 & 0.87 & 0.96 & 0.89 & 0.94 & 0.89 & 0.93 & 0.87 \\
\hline $\begin{array}{l}\text { Number of cases } \\
\text { LR } \chi^{2} \\
\text { Pseudo } \mathrm{R}^{2}\end{array}$ & $\begin{array}{l}662 \\
399.79 * * \\
0.286\end{array}$ & & $\begin{array}{l}662 \\
400.89 * * \\
0.287\end{array}$ & & $\begin{array}{l}662 \\
401.62 * * \\
0.288\end{array}$ & & $\begin{array}{l}662 \\
408.55 * * \\
0.298\end{array}$ & \\
\hline
\end{tabular}

(entries are logit maximum-likelihood estimates and their associated standard errors)

** Significant at the level of $99 \%$.

* Significant at the level of $95 \%$.

+ Significant at the level of $90 \%$. 
Table 7. Voting for the incumbent in Spain (only coefficients of the comparison among the incumbent and the main opposition party are given)

\begin{tabular}{|c|c|c|c|c|c|c|c|c|}
\hline \multirow[b]{2}{*}{ Independent Variables } & \multicolumn{2}{|l|}{ Equation 1} & \multicolumn{2}{|l|}{ Equation 2} & \multicolumn{2}{|c|}{ Equation 3} & \multicolumn{2}{|l|}{ Equation 4} \\
\hline & Coef & SE & Coef & SE & Coef & SE & Coef & SE \\
\hline $\begin{array}{l}\text { Ideological distance } \\
\text { from the incumbent }\end{array}$ & $-0.11 * *$ & 0.02 & $-0.09 * *$ & 0.02 & $-0.11 * *$ & 0.02 & $-0.12 * *$ & 0.02 \\
\hline $\begin{array}{l}\text { Ideological distance } \\
\text { from the challenger }\end{array}$ & $0.12 * *$ & 0.02 & $0.12 * *$ & 0.02 & $0.14^{* *}$ & 0.04 & $0.12 * *$ & 0.02 \\
\hline Performance $(1=$ good $)$ & $2.85^{* *}$ & 0.35 & $2.87 * *$ & 0.35 & $2.85^{* *}$ & 0.35 & $1.84^{*}$ & 0.65 \\
\hline $\begin{array}{l}\text { Index of Political } \\
\text { Knowledge }\end{array}$ & -0.07 & 0.45 & 0.28 & 0.57 & 0.16 & 0.55 & -1.26 & 0.81 \\
\hline $\begin{array}{l}\text { Ideological distance } \\
\text { from the incumbent } x \\
\text { PolKnowledge }\end{array}$ & & & -0.07 & 0.04 & & & & \\
\hline $\begin{array}{l}\text { Ideological distance } \\
\text { from the challenger } \mathrm{x} \\
\text { PolKnowledge }\end{array}$ & & & & & -0.04 & 0.05 & & \\
\hline $\begin{array}{l}\text { Performance } \mathrm{x} \\
\text { PolKnowledge }\end{array}$ & & & & & & & $2.17 * *$ & 0.95 \\
\hline Age & 0.02 & 0.01 & 0.02 & 0.01 & 0.02 & 0.01 & 0.02 & 0.01 \\
\hline Gender & $0.56+$ & 0.34 & $0.59+$ & 0.34 & $0.55+$ & 0.34 & $0.56+$ & 0.34 \\
\hline Education & $0.25^{*}$ & 0.10 & $0.25^{*}$ & 0.10 & $0.25^{*}$ & 0.10 & $0.27 * *$ & 0.10 \\
\hline $\begin{array}{l}\text { Labour Market position } \\
\text { (reference category: } \\
\text { 5. Retired) }\end{array}$ & & & & & & & & \\
\hline 1. Employed & 0.53 & 0.50 & 0.53 & 0.50 & 0.52 & 0.50 & 0.55 & 0.50 \\
\hline 2. Home-duties & $1.01 *$ & 0.48 & $1.03 *$ & 0.48 & $1.00 *$ & 0.48 & $1.05^{*}$ & 0.48 \\
\hline 3. Unemployed & 0.73 & 0.68 & 0.84 & 0.68 & 0.74 & 0.68 & 0.75 & 0.68 \\
\hline 4. Students & 0.65 & 0.92 & 0.64 & 0.93 & 0.62 & 0.92 & 0.64 & 0.93 \\
\hline Constant & $-4.43 * *$ & 1.14 & $-4.65 * *$ & 1.16 & $-4.51 * *$ & 1.14 & $-3.96 * *$ & 1.17 \\
\hline Number of cases & 794 & & 794 & & 794 & & 794 & \\
\hline $\operatorname{LR} \chi^{2}(33)$ & 713.88 & & 719.66 & & 713.88 & & 739.21 & \\
\hline Pseudo $\mathrm{R}^{2}$ & 0.410 & & 0.413 & & 0.410 & & 0.428 & \\
\hline
\end{tabular}

(entries are logit maximum-likelihood estimates and their associated standard errors)

** Significant at the level of $99 \%$.

* Significant at the level of $95 \%$.

+ Significant at the level of $90 \%$. 
The results of Tables 4 to 7 suggest that political knowledge conditions performance voting, but much less so ideological voting. This is reflected in the statistically significant coefficients for the interaction term of political knowledge and performance of equation 4 in tables 4 to 7 . These coefficients indicate that the effect of a good evaluation of performance in the chances to vote for the incumbent augments as political knowledge increases.

In contrast, the interaction term of political knowledge and ideological distance both from the incumbent and from the main opposition party is not statistically significant. Nevertheless, caution is needed in interpreting interaction terms (Brambor et. al., 2005): it is possible that the marginal effect of $X$ (in this case, ideological distance) on $Y$ (in this case, the vote) is statistically significant for relevant values of $\mathrm{Z}$ (in this case, political knowledge) even if the coefficient for the interaction term is not. To include or not an interaction term in an equation cannot be decided only on the grounds of the statistical significance of the coefficient. $^{12}$

This empirical problem is coped for as follows. I calculate the coefficients for ideological distance from the incumbent party conditioned by the minimum (0), low medium (0.33), high medium (0.66), and maximum (1) values of the index of political knowledge in each of the country samples. In this way, the conditioned coefficients for ideological distance have a substantive meaning when the interaction term is specified in each of the four equations. In addition, the corresponding standard errors associated to each of the conditioned coefficients are reported, so that the statistical significance of each of the conditioned coefficients can be better appreciated. This is done by a linear transformation of one of the variables included in the interaction term across countries. For example, when calculating the coefficient conditioned on the maximum value of the index of political knowledge, I take the old value of this index minus its maximum value, and then specify the interaction term between this transformed index and the ideological distance from the incumbent. Hence, the coefficient corresponding to this ideological distance indicates its incidence on the chances of voting for the incumbent versus its main challenger for the highest value of political

${ }^{12}$ This is what Brambor et al (2005) criticise about many articles where interaction terms were dropped because the coefficient was not statistically significant. In so doing, they missed important conditional relationships among the variables specified in their equations. 
knowledge. I used the same logic for the other three calculations of Table 8 (that is, the calculations of the coefficients conditioned on the minimum, low-medium, and high-medium values of political knowledge).

Table 8. Coefficients of ideological distance from the incumbent conditioned to different values of political knowledge

\begin{tabular}{lllll}
\hline $\begin{array}{l}\text { Levels of Political } \\
\text { Knowledge }\end{array}$ & Hungary & Poland & Portugal & Spain \\
\hline $\begin{array}{l}\text { Non conditioned } \\
\text { see tables 4 to 7: }\end{array}$ & $-0.06 * *$ & $-0.04 *$ & $-0.13 * *$ & $-0.11 * *$ \\
equation 1) & $(0.01)$ & $(0.01)$ & $(0.02)$ & $(0.02)$ \\
& & & & \\
Lowest & & & \\
(see tables 4 to 7: & $(0.03)$ & $-0.08^{*}$ & $-0.15 * *$ & $-0.09 * *$ \\
equation 2) & & $(0.04)$ & $(0.03)$ & $(0.02)$ \\
Medium-low & $-0.66^{* *}$ & $-0.06^{* *}$ & $-0.13 * *$ & $-0.10 * *$ \\
& $(0.01)$ & $(0.02)$ & $(0.02)$ & $(0.01)$ \\
Medium-high & $-0.58^{* *}$ & $-0.05^{* *}$ & $-0.12 * *$ & $-0.13 * *$ \\
& $(0.01)$ & $(0.01)$ & $(0.01)$ & $(0.01)$ \\
Highest & $-0.05^{* *}$ & $-0.03^{* *}$ & $-0.11 * *$ & $-0.15 * *$ \\
& $(0.02)$ & $(0.006)$ & $(0.03)$ & $(0.03)$ \\
& & & & \\
\end{tabular}

Note: This table shows only the "ideological distance from the incumbent" coefficients conditioned to the different values of political knowledge. The rest of the coefficients for the other independent variables remain the same as in the third column of tables 4 to 7 .

Entries are logit maximum-likelihood estimates and their associated asymptotic robust standard errors in parentheses.

** Significant at the level of $99 \%$.

* Significant at the level of $95 \%$.

+ Significant at the level of $90 \%$.

The first two sets of coefficients of Table 8 replicate the coefficients of tables 4 to 7 : they correspond to the non conditioned coefficients of ideological distance from the incumbent for equation 1 , and to the same coefficients conditioned to the minimum value of 
political knowledge (that is value 0 ) for equation 2 . The other three sets of coefficients and their associated standard errors are conditioned to the other three values of political knowledge (medium-low, medium-high, and highest). As can be seen in Table 8, the magnitudes of the conditioned coefficients are slightly higher in the intermediate categories of political knowledge in all the polities analysed here -the exception is Poland, where the magnitude is higher in the medium-high and maximum levels of political knowledge. ${ }^{13}$

Table 9. Coefficients of ideological distance from the main opposition party conditioned to different values of political knowledge

\begin{tabular}{|c|c|c|c|c|}
\hline Levels of Political Knowledge & Hungary & Poland & Portugal & Spain \\
\hline $\begin{array}{l}\text { Non conditioned } \\
\text { (see tables } 4 \text { to } 7 \text { : equation } 1 \text { ) }\end{array}$ & $\begin{array}{l}0.04 * * \\
(0.01)\end{array}$ & $\begin{array}{l}0.06 * \\
(0.01)\end{array}$ & $\begin{array}{l}0.11 * * \\
(0.01)\end{array}$ & $\begin{array}{l}0.12 * * \\
(0.02)\end{array}$ \\
\hline $\begin{array}{l}\text { Lowest } \\
\text { (see tables } 4 \text { to } 7 \text { : equation } 3 \text { ) }\end{array}$ & $\begin{array}{l}0.02+ \\
(0.01)\end{array}$ & $\begin{array}{l}0.04 \\
(0.03)\end{array}$ & $\begin{array}{l}0.09 * * \\
(0.03)\end{array}$ & $\begin{array}{l}0.14 * * \\
(0.04)\end{array}$ \\
\hline Medium-low & $\begin{array}{l}0.04 * * \\
(0.01)\end{array}$ & $\begin{array}{l}0.04^{*} \\
(0.01)\end{array}$ & $\begin{array}{l}0.10 * * \\
(0.01)\end{array}$ & $\begin{array}{l}0.13 * * \\
(0.02)\end{array}$ \\
\hline Medium-high & $\begin{array}{l}0.06^{* *} \\
(0.01)\end{array}$ & $\begin{array}{l}0.05^{* *} \\
(0.01)\end{array}$ & $\begin{array}{l}0.12 * * \\
(0.01)\end{array}$ & $\begin{array}{l}0.11 * * \\
(0.01)\end{array}$ \\
\hline Highest & $\begin{array}{l}0.08 * * \\
(0.02)\end{array}$ & $\begin{array}{l}0.06^{* * *} \\
(0.01)\end{array}$ & $\begin{array}{l}0.12 * * \\
(0.02)\end{array}$ & $\begin{array}{l}0.10 * * \\
(0.03)\end{array}$ \\
\hline
\end{tabular}

Note: This table shows only the coefficients for ideological distance from the main opposition party conditioned to the different values of political knowledge. The rest of the coefficients for the other independent variables remain the same as in the fourth column of tables 4 to 7.

Entries are logit maximum-likelihood estimates and their associated asymptotic robust standard errors in parentheses.

** Significant at the level of $99 \%$.

* Significant at the level of $95 \%$.

+ Significant at the level of $90 \%$.

13 In comparing the magnitude of the conditioned coefficients, I consider not only the coefficient themselves but also their associated standard errors. 
Table 9 presents the conditioned coefficients for the ideological distance from the main opposition party. The results are exactly the same: differences in the magnitude of the coefficients are slight, and the highest coefficients are those conditioned to the intermediate values of political knowledge -the exception is again Poland, where the highest coefficients are those for the highest level of political knowledge.

This evidence provides some limited support for our initial hypothesis on the influence of political knowledge on the propensity to use ideology when voting. Nevertheless, this effect on ideological voting appears to be non linear, and in any case very moderate. It might also be the case that the influence of political knowledge on ideological voting depends on a previous causal mechanism: voters unable to position themselves (or the two main parties) in the ideological scale can not use the logic of ideological voting. These voters are also those who more frequently do not answer questions on political knowledge. The data, however, do not allow us to distinguish non respondants who are politically ignorant from those who do not want to answer for some other reasons. ${ }^{14}$

In contrast, the influence of political knowledge on performance voting is more conclusive in tables 4 to 7 . The interaction terms are statistically significant in the four countries. The results of Table 10 show with no exception that the magnitudes of the coefficients corresponding to assessments of governmental performance are higher as the level of political knowledge increases. For instance, if we consider the lowest level of political knowledge, the coefficient is not statistically significant in Portugal. And in Poland, the effect of governmental performance is statistically significant only for the highest level of political knowledge. ${ }^{15}$ I shall now conclude this paper with a brief discussion of the implications of these empirical findings.

\footnotetext{
${ }^{14}$ I have done a bivariate analysis of those respondents who do not position themselves in the ideological scale and the political knowledge index. The relationship is not especially relevant for Spain and Portugal (with a V Cramer equal to 0.23 and 0.21 respectively); it is higher for Hungary and especially Poland (with a V Cramer equal to 0.32 and 0.39 respectively). In these two countries, those who do not respond to the ideological questions are also those presenting the lowest levels of political knowledge.

In contrast the relationship between those respondents who do not answer the performance question and the political knowledge index is of smaller magnitude across countries: V Cramer of 0.11 in Hungary, 013 both in Spain and Portugal, and 0.22 in Poland. These results are available to the interested reader.

${ }^{15}$ Again, in comparing the magnitude of the conditioned coefficients, I consider not only the coefficients themselves but also their associated standard errors.
} 
Table 10. Coefficients of performance voting conditioned to different values of political knowledge

\begin{tabular}{lllll}
\hline & Hungary & Poland & Portugal & Spain \\
\hline $\begin{array}{l}\text { Levels of Political Knowledge conditioned } \\
\text { (see tables 4 to 7: equation 1) }\end{array}$ & $\begin{array}{l}3.17^{* *} \\
(0.31)\end{array}$ & $\begin{array}{l}0.84^{*} \\
(0.39)\end{array}$ & $\begin{array}{l}1.77^{* *} \\
(0.26)\end{array}$ & $\begin{array}{l}2.85 * * \\
(0.35)\end{array}$ \\
& & & & \\
Lowest & $2.34^{* *}$ & -3.22 & 0.7 & $1.84^{* *}$ \\
(see tables 4 to 7: equation 4) & $(0.54)$ & $(1.99)$ & $(0.53)$ & $(0.65)$ \\
Medium-low & $3.06^{* *}$ & -1.69 & $1.5 * *$ & $2.5^{* *}$ \\
& $(0.31)$ & $(1.19)$ & $(0.30)$ & $(0.36)$ \\
Medium-high & $3.79^{* *}$ & -0.16 & $2.31^{* *}$ & $3.28^{* *}$ \\
& $(0.47)$ & $(0.62)$ & $(0.38)$ & $(0.40)$ \\
Highest & $4.51^{* *}$ & $1.36^{* *}$ & $3.11^{* *}$ & $4.02^{* *}$ \\
& $(0.68)$ & $(0.45)$ & $(0.58)$ & $(0.48)$ \\
& & & & \\
\hline
\end{tabular}

Note: This table shows only the coefficients for performance conditioned to the different values of political knowledge. The rest of the coefficients for the other independent variables remain the same as in the last column of tables 4 to 7 .

Entries are logit maximum-likelihood estimates and their associated asymptotic robust standard errors in parentheses.

** Significant at the level of $99 \%$.

* Significant at the level of $95 \%$.

+ Significant at the level of $90 \%$.

\section{Conclusions}

This paper set out to asses the effects of political knowledge on political choices. The empirical analysis has shown such effects on voting decisions. For performance voting the results are conclusive: the influence of performance on the vote is of greater magnitude as the level of political knowledge increases. There are no exceptions to this. Moreover, in two of the four polities (Portugal and Poland), performance does not influence voting among the less knowledgeable citizens. This suggests that a politically informed citizenry is a necessary (though not sufficient) condition for a democratic control of governments based on their past 
performance. In contrast, for the case of ideological voting the results are less conclusive. There is some evidence that the likelihood of using ideology in order to decide which party to vote is higher among voters with intermediate levels of political knowledge than among those presenting the lowest level of political expertise. But this evidence is fairly limited. Thus, my empirical conclusions do not appear to support Zaller's $(1992,2004)$ thesis that wellinformed voters use ideological proximity as a criterium for voting, whereas poorly-informed ones use assessments of past performance. The conclusions, on the contrary, are congruent with Fearon's views about the strong informative requirements of performance voting. When "the electorate's ability to monitor what politicians do is poor, then the force of the electoral sanction is weak" (Fearon, 1999:82). Low degrees of political knowledge lead voters to select politicians according to ideology.

While political scientists have long argued about the benefits of an informed and knowledgeable citizenry (Key, 1966; Mayhew, 1974; Manin, Przeworski, and Stokes, 1999; Pitkin, 1967), relatively few empirical studies have tested the effects of political knowledge on voting decisions. These have shown that election outcomes could be considerably different if the electorate as a whole was generally well informed about politics (Bartels, 1996). The main contribution of this paper therefore is that the effect of political knowledge on voting is not homogeneous: it varies according to the different logics of voting. If rewards and sanctions for past performance are crucial for governments to be representative, this paper provides evidence that this retrospective control depends more on the political knowledge of citizens than if they use ideology to select the incumbent. 


\section{APPENDIX}

Table A.1. Descriptive statistics of all the variables included in each equation

\begin{tabular}{|c|c|c|c|c|c|c|c|c|c|c|}
\hline & \multicolumn{5}{|c|}{ Hungary } & \multicolumn{5}{|c|}{ Poland } \\
\hline Variables & $N$ & Mean & $\begin{array}{l}\text { Std, } \\
\text { Dev, }\end{array}$ & Min & Max & $N$ & Mean & $\begin{array}{l}\text { Std, } \\
\text { Dev, }\end{array}$ & Min & Max \\
\hline Declared vote & 990 & 1.72 & 0.68 & 1 & 3 & 982 & 2.01 & 1.10 & 1 & 4 \\
\hline $\begin{array}{l}\text { Ideological distance } \\
\text { from the incumbent }\end{array}$ & 1042 & 22.80 & 29.73 & 0 & 100 & 1283 & 28.50 & 29.80 & 0 & 100 \\
\hline $\begin{array}{l}\text { Ideological distance } \\
\text { from the challenger }\end{array}$ & 1050 & 20.19 & 28.46 & 0 & 100 & 1329 & 21.61 & 26.96 & 0 & 100 \\
\hline Performance & 1165 & 0.51 & 0.50 & 0 & 1 & 1649 & 0.10 & 0.30 & 0 & 1 \\
\hline Level of Polknowledge & 1200 & 0.38 & 0.29 & 0 & 1 & 1794 & 0.76 & 0.35 & 0 & 1 \\
\hline Age & 1198 & 50.32 & 17.36 & 18 & 92 & 1794 & 47.28 & 17.49 & 18 & 98 \\
\hline Gender & 1199 & 0.39 & 0.49 & 0 & 1 & 1794 & 0.43 & 0.49 & 0 & 1 \\
\hline Education & 1199 & 1.81 & 0.63 & 1 & 3 & 1794 & 4.36 & 1.34 & 1 & 7 \\
\hline Employed & 1184 & 0.47 & 0.50 & 0 & 1 & 1655 & 0.42 & 0.49 & 0 & 1 \\
\hline Home-duties & 1184 & 0.04 & 0.19 & 0 & 1 & 1655 & 0.10 & 0.30 & 0 & 1 \\
\hline Unemployed & 1184 & 0.05 & 0.21 & 0 & 1 & 1655 & 0.13 & 0.33 & 0 & 1 \\
\hline Students & 1184 & 0.03 & 0.18 & 0 & 1 & 1655 & 0.05 & 0.21 & 0 & 1 \\
\hline Retired & 1184 & 0.42 & 0.49 & 0 & 1 & 1655 & 0.31 & 0.46 & 0 & 1 \\
\hline
\end{tabular}

Table A.2. Descriptive statistics of all the variables included in each equation

\begin{tabular}{|c|c|c|c|c|c|c|c|c|c|c|}
\hline \multicolumn{6}{|c|}{ Portugal } & \multicolumn{5}{|c|}{ Spain } \\
\hline Variables & $N$ & Mean & $\begin{array}{l}\text { Std, } \\
\text { Dev, }\end{array}$ & Min & Max & $N$ & Mean & $\begin{array}{l}\text { Std, } \\
\text { Dev, }\end{array}$ & Min & $\operatorname{Max}$ \\
\hline Declared vote & 784 & 1.78 & 0.74 & 1 & 3 & 942 & 1.98 & 0.91 & 1 & 4 \\
\hline $\begin{array}{l}\text { Ideological distance } \\
\text { from the incumbent }\end{array}$ & 1092 & 8.23 & 14.24 & 0 & 100 & 1044 & 24.18 & 26.25 & 0 & 100 \\
\hline $\begin{array}{l}\text { Ideological distance } \\
\text { from the challenger }\end{array}$ & 1091 & 11.87 & 18.53 & 0 & 100 & 1044 & 6.83 & 13.11 & 0 & 100 \\
\hline Performance & 1193 & 0.20 & 0.40 & 0 & 1 & 1044 & 0.44 & 0.50 & 0 & 1 \\
\hline Level of Polknowledge & 1303 & 0.47 & 0.29 & 0 & 1 & 1212 & 0.47 & 0.35 & 0 & 1 \\
\hline Age & 1303 & 45.26 & 16.62 & 18 & 80 & 1212 & 46.09 & 17.89 & 18 & 94 \\
\hline Gender & 1303 & 0.44 & 0.50 & 0 & 1 & 1212 & 0.49 & 0.50 & 0 & 1 \\
\hline Education & 1295 & 4.41 & 2.04 & 1 & 8 & 1206 & 4.45 & 1.81 & 1 & 8 \\
\hline Employed & 1293 & 0.60 & 0.49 & 0 & 1 & 1193 & 0.44 & 0.50 & 0 & 1 \\
\hline Home-duties & 1293 & 0.11 & 0.32 & 0 & 1 & 1193 & 0.21 & 0.41 & 0 & 1 \\
\hline Unemployed & 1293 & 0.04 & 0.20 & 0 & 1 & 1193 & 0.09 & 0.28 & 0 & 1 \\
\hline Students & 1293 & 0.03 & 0.18 & 0 & 1 & 1193 & 0.06 & 0.24 & 0 & 1 \\
\hline Retired & 1293 & 0.21 & 0.41 & 0 & 1 & 1193 & 0.20 & 0.40 & 0 & 1 \\
\hline
\end{tabular}




\section{References}

Andersen, Robert, Anthony Heath, and Richard Sinnot. 2001. "Political Knowledge and Electoral Choices". CREST Working Paper number 87.

Althaus, Scott. 2003. Collective Preferences in Democratic Politics. Cambridge, Cambridge University Press.

Bartels, Larry. 1996. "Uninformed Votes: Information Effects in Presidential Elections". American Journal of Political Science. 40-1: 194-230

Bartle, John. 1997. "Political Awareness and Heterogeneity in Models of Voting: Some Evidence from the Recent British Election Studies". En Charles Pattie, David Denver, Justin Fisher y Steve Ludlam (eds.), British Elections and Parties Review (vol. 7). London: Frank Cass.

Bennet, Stephen. 1988. "Know-nothing revisited: The Meaning of Political Ignorance Today”. Social Science Quarterly, 69: 476-90.

Bennet, Stephen. 1989. “Trends in Americans' Political Information, 1967-1987”. American Politics Quarterly. 17: 422-35.

Bennet, Stephen. 1995. “Americas' Knowledge of Ideology, 1980-1992”. American Politics Quarterly. 23: 259-278.

Brambor, Thomas, William Roberts Clark, and Matt Golder. 2005. "Understanding Interaction Models: Improving Empirical Analyses". Political Analysis. 13: 1-20

Converse, Philip. 1964. "The Nature of Belief Systems in Mass Publics”. In David Apter. (ed): Ideology and Discontent. New York: Free Press.

Converse, Philip. 1970. "Attitudes and Non Attitudes: Continuation of a Dialogue". In Edward Tufte $(e d)$. The Quantitative Analysis of Social Problems. Reading, (Mass.): Addison-Wesley.

Costa Lobo, Marina, Pedro Magalhaes and André Freire. 2004. "Introduçao". In Freire, André, Marina Costa Lobo, and Pedro Magalhaes (eds.) Portugal a Votos: As eleiçoes legislativas de 2002.Imprensa de Ciencias Sociais, Lisboa: 25-34.

Delli Carpini, Michael and Scott Keeter. 1996. What Americans Know about Politics and Why it Matters. New Haven: Yale University Press.

Downs, Anthony. 1957. An Economic Theory of Democracy. New York: Harper and Row.

Fearon, James. 1999. "Electoral Accountability and the Control of Politicians: Slecting Good Types versus Santioning Poor Performance". In Adam Przeworski, Susan C. Stokes, 
and Bernard Manin (eds.), Democracy, Accountability, and Representation. New York: Cambridge University Press.

Gómez, Brad and Matthew Wilson. 2001. "Political Sophistication and Economic Voting in the American Electorate: a Theory of Heterogeneous Attribution". American Journal of Political Science. 45-4: 899-914.

Gómez, Brad and Matthew Wilson. 2006. "Cognitive Heterogeneity and Economic Voting: A Comparative Analysis of Four Democratic Electorates". American Journal of Political Science. 50-1: 127-145.

Key, V.O. Jr. 1966. The Responsible Electorate: Rationality in Presidential Voting: 19361960. Cambridge: Harvard University Press

Luskin, Robert. 1990. "Explaining Political Sophistication”. Political Behaviour. 12: 331361.

Kiewiet, D. Roderick. 1983. Macro-economics and Micro-politics: the Electoral Effects of Economic Issues. Chicago: the University of Chicago Press.

Kinder, Donald R. and Roderick Kiewiet. 1979. "Economic Discontent and Political Behaviour: The Role of Personal Grievances and Collective Economic Judgements in Congressional Voting". American Journal of Political Science. 23: 495-517.

Kinder, Donald R. and Roderick Kiewiet. 1981. "Sociotropic Politics". British Journal of Political Science. 11: 129-61

Kramer, Gerald H. 1971. "Short-Term Fluctuations in U.S. Voting Behaviour, 1896-1964". American Political Science Review. 65: 131-43.

Kramer, Gerald H. 1983. "The Ecological Fallacy Revisited: Aggregate versus Individual Level Findings on Economics and Elections, and Sociotropic Voting". American Political Science Review. 77: 92-111.

Krause, George A. 1997. "Voters, Information Heterogeneity, and the Dynamics of Aggregate Economic Expectations". American Journal of Political Science 41: 11701200 .

Manin, Bernard, Adam Przeworski, and Susan Stokes. 1999. "Elections and Representation" in Adam Przeworski, Susan Stokes, and Bernard Manin (eds). Democracy, Accountability and Representation. New York: Cambridge University Press.

Mayhew, David R. 1974. Congress: The Electoral Connection. New Haven: Yale University Press

Millner, Henry. 2002. Civic Literacy. How Informed Citizens Make Democracy Work. Tufts University. University Press of New England. 
Pitkin, Hanna F. 1967. The Concept of Representation. Berkeley: University of California Press.

Popkin, Samuel L. 1991. The Reasoning Voter. Chicago: The University of Chicago Press.

Sinnot, Richard. 2000. "Knowledge and the Position of Attitudes to a European Foreign Policy on the Real-to-Random Continuum". International Journal of Public Opinion Research. 12: 113-137.

Sniderman, Paul M., Richard A. Brody, and Philip E. Tetlock. 1991. Reasoning and Choice. Explorations in Political Psychology. New York: Cambridge University Press.

Toka, Gabor. 2003. "Can Voters Be Equal? A Cross-National Analysis. Part 1". The Review of Sociology. 9: 51-72.

Torcal, Mariano and Guillem Rico. 2004. "The 2004 Spanish General Election: in the Shadow of Al-Qaeda?'. South European Society \& Politics. 9-3: 107-121.

The Comparative Study of Electoral Systems (www.cses.org). 2005. CSES MODULE 2 Third Advance Release [dataset]. Ann Arbor, Michigan: University of Michigan, Center for Political Studies. June 29, 2005

Zaller, John R. 1992. The Nature and Origins of Mass Opinion. New York: Cambridge University Press

Zaller, John R. 2004. "Floating Voters in US Presidential Elections: 1948-2000". In Paul Sniderman and Willem Saris (eds.). The Issue of Beliefs: Essays in the Intersection of Nonattitudes and Attitude Change. Amsterdam: University of Amsterdam Press. 